\title{
Akomodasi dalam Refraksi
}

\author{
Rinda Wati
}

\section{Abstrak}

Akomodasi merupakan mekanisme perubahan kekuatan refraksi mata dengan merubah bentuk dari kristalin lensa. Titik fokus posterior berpindah kedepan mata selama akomodasi. Dengan adanya proses tersebut, titik jauh lebih dekat ke mata. Kemampuan akomodasi ketika otot siliaris berkontraksi sebagai respon bagi stimulasi parasimpatetik dan relaksasi serabut zonular. Pergerakan dari respon akomodasi merupakan hasil dari peningkatan konveksitas lensa ( terutama pada permukaan anterior). Amplitudo akomodasi (dalam D) atau sebagai jarak dari akomodasi. Jarak antara titik jauh mata dan titik terdekat dimana mata dapat menjaga fokus (titik dekat). Lensa kehilangan elastisitasnya diakibatkan proses penuaan dan respon akomodasi berkurang dinamakan presbyopia.

Kata kunci: Akomodasi, refraksi

\begin{abstract}
Accommodation is the mechanism by which the eye changes refractive power by altering the shape of its crystalline lens. The posterior focal point is moved forward in the eye during accommodation. Correspondingly, the far point moves closer to the eye.Accommodative effort when the ciliary muscle contracts in response to parasympathetic stimulation and relaxation of zonular fibers. The movement of Accommodative response results from the increase in lens convexity (primarily the anterior surface). Amplitude of accommodation (in D)or as the range of accommodation. The distance between the far point of the eye and the nearest point at which the eye can maintain focus (near point). Lens loses elasticity due to aging process, andthe accommodative response wanes is call presbyopia.
\end{abstract}

Keywords: Accomodation, refraction

Affiliasi penulis : Bagian Mata, Fakultas Kedokteran Universitas Andalas

Korespondensi : Rinda Wati rindawatispm@yahoo.co.id

\section{Pendahuluan}

Akomodasi adalah suatu mekanisme dimana mata merubah kekuatan refraksinya dengan merubah ketajaman lensa kristalin. Ada banyak teori yang telah dikemukan tentang bagaimana proses akomodasi dapat terjadi pada mata. Teori yang paling tua dikenal yaitu teori vitreus oleh Cramers, lalu dikembangkan juga teori akomodasi relaksasi oleh Helmholtz, teori kontraksi zonula oleh Tscherning, dan masih banyak teori akomodasi lainnya. Sementara itu untuk memfokuskan benda yang berjarak dekat otot siliaris melakukan kontraksi sehingga membuat lensa mata menjadi tebal. Daya akomodasi mata dibatasi oleh dua titik yaitu titik dekat ( punctum proximum ), yaitu titik terdekat yang masih dapat dilihat dengan jelas oleh mata. Titik jauh ( punctum remotum ), yaitu titik terjauh yang masih dapat dilihat dengan jelas oleh mataKebanyakan dari masalah penglihatan berhubungan dengan kemampuan akomodasi, seperti akomodasi yang terlalu besar, terlalu kecil ataupun terlalu lambat. Untuk dapat menilai kemampuan akomodasi seseorang maka dapat dilakukan pemeriksaan akomodasi baik monokular maupun binokular dengan menggunakan metode metode Push Up ataupun metode Lensa Sferis. Yang dinilai yaitu akomodasi jarak dekat, amplitudo akomodasi dan range akomodasi sehingga dapat diidentifikasi kemampuan akomodasi mata.

Helmholtz mengajukan teori relaksasi akomodasinya berdasarkan perubahan ukuran serat serat purkinje di permukaan anterior lensa kristalin (sama halnya dengan eksperimen yang telah dilakukan oleh Cramer) untuk mendukung gagasannya bahwa lensa kristalin sebenarnya berperan besar terhadap akomodasi. Dia mengamati saat mata tidak berakomodasi dan melihat jauh, maka otot - otot siliaris akan berelaksasi dan serat - serat zonula elastis jadi teregang, ini akan menarik lensa kristalin ke arah luar ke ekuator dan lensa menjadi datar Ini merupakan teori yang sangat berlawanan dengan teori Helmholtz's. Tscherning menggunakan sebuah 
ophthalmophacometer yang telah ia rancang untuk mengamati gambar yang dibentuk oleh permukaan anterior dan posterior lensa kristalin. Dia berpendapat bahwa konstraksi otot siliaris akan meningkatkan ketegangan serat - serat zonula, sehingga merubah ketajaman lensa tanpa merubah ketebalan ataupun diameter lensa. "Posisi Tscherning " merupakan suatu kondisi saat lensa kristalin dikeluarkan dari bola mata, dan ini tampak seperti kondisi penglihatan jauh dan tidak berakomodasi seperti teori yang diajukan oleh Helmholtz

\section{Pembahasan}

Akomodasi merupakan salah satu dari 3 komponen untuk melihat objek dalam jarak dekat yang disebut respon dekat atau refleks dekat. Komponen respon dekat meliputi akomodasi, konvergensi, dan miosis pupil yang normalnya bekerja bersamaan, namun masing - masingnya dapat diuji secara terpisah. Misalnya akomodasi dapat distimulasi dengan lensa plus atau menguatkan stimulus akomodasi dengan lensa minus tanpa menstimulasi konvergensi atau miosis. Sementara itu dapat juga menggunakan prisma base - out berkekuatan lemah untuk menstimulasi konvergensi tanpa merubah akomodasi.

Terdapat 3 aspek akomodasi, yaitu:

- Akomodasi jarak dekat ( near point of akomodation / NPA )

NPA yaitu jarak objek terdekat dari mata yang dapat dilihat dengan jelas.

- Amplitudo akomodasi

Amplitudo akomodasi yaitu kekuatan lensa yang memberikan visualisasi visual yang jelas. Kekuatan ini terukur dalam satuan dioptri ( D ) dan didapat dengan membagi 100 dengan NPA dalam satuan $\mathrm{cm}$. Misalnya pasien dengan NPA $25 \mathrm{~cm}$, maka amplitudo akomodasinya adalah 100/25= 4 D.

- $\quad$ Range akomodasi ( range accommodation ) Range akomodasi yaitu jarak antara objek terjauh dan terdekat yang masih dapat dilihat oleh mata dengan jelas.
Gejala pasien dengan gangguan akomodasi tidaklah spesifik, tapi beberapa keluhan pasien mungkin dapat membantu mendeteksi gangguan akomodasi. Pasien - pasien dengan penurunan kemampuan akomodasi biasanya mengeluhkan kabur saat melihat dekat, tetapi tidak saat melihat jauh. Pasien yang paling sering mengeluhkan masalah akomodasi yaitu pasien presbiopia, biasanya pasien ini akan mengeluhkan harus menjauhkan objek yang ingin dilihatnya. Beberapa pasien dengan penurunan akomodasi kadang dapat mengeluhkan diplopia monokular, tidak nyaman saat membaca jarak dekat, lambat saat merubah fokus fiksasi dari jarak jauh ke dekat ataupun dari jarak dekat ke jauh. Beberapa pasien dapat juga mengeluhkan sakit kepala, intoleransi terhadap cahaya, ataupun gejala astenopia lainnya.

Akomodasi yang berlebihan atau spasme akomodasi ditandai dengan penglihatan yang baik saat melihat dekat dan visualisasi yang jelek saat melihat jauh. Objek visual dapat juga terlihat lebih besar ataupun lebih kecil (makropsia atau mikropsia) dari orang normal, dan sakit kepala di bagian depan.

\section{Pemeriksaan Akomodasi}

Pemeriksaan akomodasi dilakukan untuk menilai kemampuan akomodasi mata seseorang. Pemeriksaan ini juga termasuk dalam pemeriksaan mata rutin dan pemeriksaan amplitudo akomodasi dapat diperiksa monokular dan binokular. Teknik pemeriksaan akomodasi dilakukan untuk menilai renge dan amplitudo akomodasi. Kendala yang paling sering ditemui dalam aplikasi klinisnya yaitu nilai end point yang subjektif. Langkah pertama dalam menilai komponen akomodasi yaitu memperoleh nilai refraksi yang adekuat dari kedua jarak penglihatan jauh dan dekat. Pada anak - anak dan beberapa orang dewasa, refraksi sikloplegik dengan menggunakan cyclopentolate dibutuhkan untuk mencegah pasien melakukan akomodasi dan ini dapat meningkatkan derajat miopia yang membutuhkan koreksi refraksi.

\section{AmplitudoAkomodasi Monokular}

Amplitudo akomodasi monokular yaitu limit dioptri dimana pasien dapat mengidentifikasi dengan 
jelas organ target yang kecil (20/20) pada jarak terdekat dengan satu mata. Pemeriksaan akomodasi yang dapat dilakukan yaitu metode Push Up dan metode Lensa Sferis.

\section{Amplitudo Akomodasi Binokular}

Amplitudo akomodasi binokular yaitu limit dioptri dimana pasien dapat memfusikan dengan jelas organ target yang kecil dengan kedua mata. Pemeriksaan yang dapat dilakukan adalah metode Push Up dan metode Lensa Sferis.

\section{Metode Push Up}

Near point of accomodation (NPA) merupakan salah satu komponen akomodasi yang paling mudah dinilai praktek sehari - hari. Pemeriksaannya dapat dilakukan dengan menggunakan alat seperti penggaris yang berskala seperti : Prince, Krimsky, ataupun penggaris Berrens ( Gambar 1 dan gambar 2). Alat - alat ini berupa penggaris sederhana dengan penanda dalam $\mathrm{cm}$ dan dioptri yang memiliki chart dengan huruf - huruf snellen. Teknik untuk menilai akomodasi dengan alat ini disebut metode Push Up.

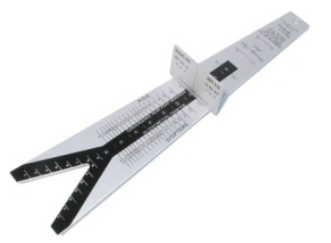

Gambar 1. Penggaris Krimsky

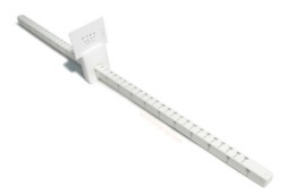

Gambar2. Penggaris Berrens

Caranya dengan dengan menempatkan target kecil yang secara perlahan - lahan digerakkan mendekati pasien hingga target dapat terlihat dengan jelas ( Gambar 2). Daya akomodasi terjadi karena target kecil pada jarak dekat digerakkan mendekati pasien. Konvergensi lensa juga berubah bersamaan dengan jarak target. Saat target digerakkan terjadi peningkatan konvergensi akomodasi, peningkatan vergensi fusional untuk mempertahankan fusi.
Pemeriksaan monokular dilakukan pada satu mata dengan mata yang lainnya ditutup.

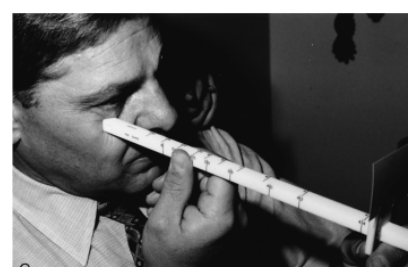

Gb 3. Pemeriksaan akomodasi metode Push Up

Prinsip pemeriksaan ini ialah jarak target yang dekat dapat meningkatkan daya akomodasi mata. Ukuran tulisan pada chart juga penting untuk diperhatikan karena tulisan yang paling kecil akan menimbulkan respon akomodasi yang paling kuat. Pada saat menggerakkan chart dari jarak jauh hingga menuju mata pasien dimana pasien dapat melihat dengan jelas sebelum target terlihat kabur kembali adalah nilai NPA dan dinilai dalam $\mathrm{cm}$. Jika nilai NPA telah didapat, maka amplitudo akomodasi bisa diperoleh dengan membagi 100 dengan nilai NPA dalam $\mathrm{cm}$.

Saat mengintrepretasikan hasil pemeriksaan akomodasi dengan menggunakan metode push up, pasien haruslah kooperatif saat pemeriksaan. Pastikan juga pencahayaan ruangan pemeriksaan yang edekuat, karena pencahayaan merupakan salah satu faktor penting yang mempengaruhi hasil pemeriksaan.

Range akomodasi dapat juga dinilai dengan pemeriksaan yang sama denga amplitudo akomodasi. Pasien diinstruksikan untuk memberitahukan saat objek target mulai kabur saat didekatkan dan kapan kabur kembali saat objek target di jauhkan. Range akomodasi lalu dihitung dengan menentukan titik jauh dan titik dekat dalam dioptri ( membagi 100 dengan masing - masing jarak dalam $\mathrm{cm}$ ), lalu kurangi nilai titik jauh dengan titik dekat.

Dengan menggunakan metode Push Up, Duane pada tahun 1994 mengembangkan data hubungan normatif berupa tabel antara usia dan amplitudo akomodasi yang masih digunakan hingga sekarang ( Tabel 1 ). Menurut Duane terdapat penurunan kemampuan akomodasi linear hingga usia 52 tahun, dan setelah itu daya akomodasi mata pun hilang. 


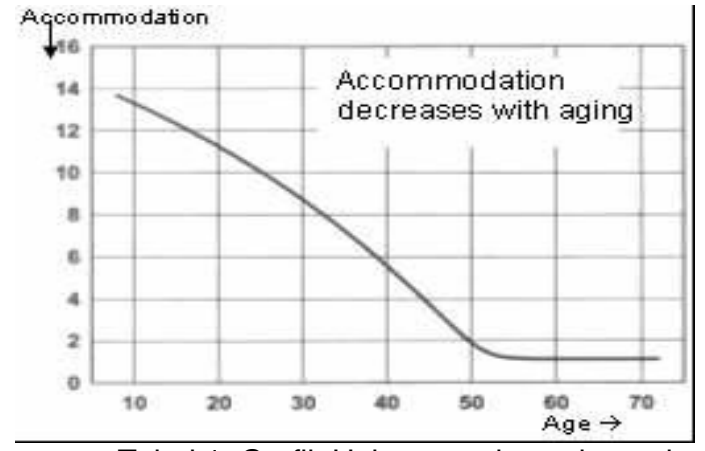

Tabel 1. Grafik Hubungan daya akomodasi

terkait usia

Metode Lensa Sferis

Prinsipnya daya akomodasi terjadi karena melihat target kecil pada jarak yang dekat dengan menggunakan lensa sferis minus maksimal, lalu diberikan lensa sferis plus secara bertahap hingga target terlihat kabur kembali. Pada pemeriksaan ini mata pasien difiksasi dengan target baca pada jarak $40 \mathrm{~cm}$, dan stimulasi dengan penambahan lensa minus secara bertahap hingga didapatkan visualisasi organ target yang kabur. Lalu akomodasi diistirahatkan dengan menambahkan lensa positif hingga target visual yang jelas kembali terlihat kabur. Jumlah lensa yang digunakan merupakan nilai amplitudo akomodasi. Sebagai contoh, jika pasien menerima sferis - 4,00 D sebelum organ target terlihat kabur, dan dapat menerima lagi $+2,5 \mathrm{D}$ sebelum target yang jelas terlihat mulai kabur kembali, maka total sferis amplitudo akomodasi yaitu 4,00 D + 2,5 D = $6,50 \mathrm{D}$.

Sama halnya dengan metode push up, untuk memperoleh nilai NPA dan amplitudo akomodasi, metode lensa sferis hanya dapat dilakukan pada pasien - pasien yang kooperatif. Saat lensa minus dipasangkan terjadi peningkatan konvergensi akomodasi, dan peningkatan fusi divergen untuk menjaga fusi objek yang tidak bergerak

\section{Refraktometer}

Metode pemeriksaan yang paling objektif dalam menilai akomodasi yaitu menggunakan refraktometer (Gambar 8). Kebanyakan dari alat ini menggunakan lensa sferis minus yang ditingkatkan untuk menstimulasi akomodasi, lalu diukur respon akomodasinya. Alternatif lainnya yaitu menstimulasi akomodasi tanpa menggunakan lensa tapi secara farmakologi dengan menggunakan agonis muskarinik topikal, seperti pilokarpin lalu diukur respon akomodasinya dengan refraktometer.

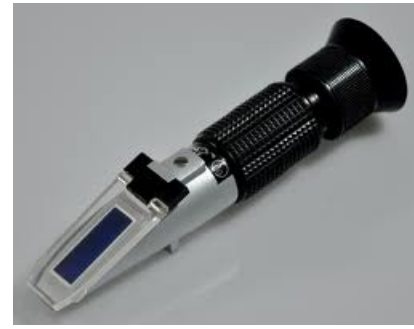

Gambar 4. Refraktometer

\begin{tabular}{rc}
\hline Age & Average Accommodative Amplitude \\
\hline 8 & $14.0( \pm 2 \mathrm{D})$ \\
12 & $13.0( \pm 2 \mathrm{D})$ \\
16 & $12.0( \pm 2 \mathrm{D})$ \\
20 & $11.0( \pm 2 \mathrm{D})$ \\
24 & $10.0( \pm 2 \mathrm{D})$ \\
28 & $9.0( \pm 2 \mathrm{D})$ \\
32 & $8.0( \pm 2 \mathrm{D})$ \\
36 & $7.0( \pm 2 \mathrm{D})$ \\
40 & $6.0( \pm 2 \mathrm{D})$ \\
44 & $4.5( \pm 1.5 \mathrm{D})$ \\
48 & $3.0( \pm 1.5 \mathrm{D})$ \\
52 & $2.5( \pm 1.5 \mathrm{D})$ \\
56 & $2.0( \pm 1.0 \mathrm{D})$ \\
60 & $1.5( \pm 1.0 \mathrm{D})$ \\
64 & $1.0( \pm 0.5 \mathrm{D})$ \\
68 & $0.5( \pm 0.5 \mathrm{D})$ \\
\end{tabular}

Tabel 2. Tabel amplitudo akomodasi populasi normal

\section{Disfungsi Akomodasi}

Disfungsi akomodasi pernah dilaporkan terjadi 60 - $80 \%$ pasien dengan masalah penglihatan binokular. Pasien dengan insufisiensi akomodasi biasanya mengeluhkan penglihatan kabur, kabur membaca pada jarak dekat, susah berkonsentrasi dan kadang dapat disertai dengan sakit kepala. Faktor resiko terjadinya disfungsi akomodasi yaitu karena kebutuhan untuk mempertahankan peningkatan akomodasi saat melihat target visual pada jarak dekat, sehingga menyebabkan kelelahan sistem akomodasi.

Terdapat klasifikasi tentang disfungsi akomodasi yang di populerkan oleh Duke - Elder, dimana ada lima jenis disfungsi akomodasi yaitu ${ }^{21}$ :

1. Insufisiensi Akomodasi

Insufisiensi akomodasi terjadi saat amplitudo akomodasi (AA) lebih rendah dari normal sesuai usia 
pasien, dan keadaan ini tidak terkait dengan sklerosis lensa kristalin. Gejalanya muncul saat pasien tidak mampu mempertahankan akomodasinya.

\section{III - Sustained Accommodation}

Kondisi ini terjadi pada kondisi dimana amplitudo akomodasi normal, tapi muncul kelelahan sistem akomodasi saat stimulus akomodasi diulangi. Gejala yang paling sering ditemui pada pasien ini yaitu penglihatan yang kabur setelah bekerja lama pada jarak dekat.

\section{Accommodation Infacility}

Kondisi ini muncul saat sistem akomodas bergerak lambat untuk berubah, atau saat terjadi keterlambatan respon akomodasi terhadap stimulus akomodasi. Pasien biasanya mengeluhakan kabur saat melihat jauh setelah mempertahankan akomodasi. Beberapa ahli berpendapat bahwa accommodation Infacility adalah prekursor untuk miopia.

\section{Paralarisis of Accommodation}

Paralarisis of Accommodation merupakan kondisi yang cukup jarang terjadi dimana sistem akomodasi gagal untuk berespon terhadap stimulus. Kondisi dapat disebabkan oleh penggunaan obat obatan sikloplegik, trauma, penyakit okular atau sistemik dan keracunan. Keadaan ini dapat terjadi unilateral dan bilateral.

\section{Spasme Akomodasi}

Spasme akomodasi terjadi akibat stimulus yang berlebihan dari sistem persarafan parasimpatis, dan spasme akomodasi dapat dikaitkan dengan kelelahan. Hal ini dapat disebabkan oleh penggunaan obat kolinergik topikal ataupun sistemik, trauma dan myastenia gravis.

\section{Kesimpulan}

- Akomodasi adalah kemampuan mata untuk merubah kekuatan refraksinya dengan merubah ketajaman lensa kristalin agar bayangan objek visual dapat tepat jatuh di retina sehingga diperoleh visualisasi objek yang lebih jelas.

- Ada banyak teori yang berkembang untuk menjelaskan tentang bagaimana mata bisa melakukan akomodasi, namun teori yang paling banyak diterima yaitu teori akomodasi relaksasi oleh Helmholtz.

- Kebanyakan dari masalah penglihatan berkaitan dengan akomodasi yang tidak adekuat, sehingga disarankan untuk melakukan pemeriksaan akomodasi sebagai bagian dari pemeriksaan mata rutin.

- Yang dinilai dari pemeriksaan akomodasi yaitu tiga aspek akomodasi meliputi akomodasi jarak dekat (NPA), amplitudo akomodasi dan range akomodasi.

- Pemeriksaan akomodasi dapat dilakukan pada satu mata ataupun dua mata dengan menggunakan metode Lensa Sferis, metode Push Up secara subjektif dan dengan alat refraktometer secara objektif.

\section{Daftar Pustaka}

1. Glasser Adrian, In: Hyperopia and Presbyopia, The Helmholttz Mechanism of Accommodation, Marcel Dekker, New York, 2003: p27-46

2. Liesegang TJ. Skuta GL. Cantor LB. Optic of the Human Eye In Clinical Optic.

Chapter 3. American Academy of Ophthalmology. San Fransisco. 2014: pp.116 - 117

3. Kaufman PI. Glasser A. Acomodation and Presbyopia, In : Adlers's Physiology of the Eye, 12 th edition, Mosby Inc. St. Louis Missouri. 2012

4. Ciuffreda KJ. Accommodation, the pupil and presbyopia. In: Benjamin WJ, editor. Borish's clinical refraction. Missouri: ButterworthHeineman, 2006; p. 93-114.

5. SmolekMK, Klyce SD, in: Hyperopia and Presbyopia, Basic of hyperopia and Presbyopia, Marcel Dekker, New York, 2003: p27-46

6. Michaels DD. Accommodation, Vergences, and Heterophorias. In: Michaels DD, eds. Visual Optics and Refraction, 3rd ed. St. Louis: C.V. Mosby, 2005:Chap. XVIII

7. Duke-Elder S. Adjustments to the optical system: accommodation. In: DukeElder S, eds. System of Ophthalmology: Ophthalmic Optics and Refraction, St. Louis: C.V. Mosby, 2007; Vol.V, Chap. IV

8. Cooper S Jeffrey. Accommodation Dysfunction in Ophmetric Clinical Practise Guideline Care of the Patient with Accommodative and Vergence Dysfunction. Lindbergh. 2010: pp. 4 - 10 
9. Glasser A, Campbell MCW. Presbyopia and the optical changes in the human crystalline lens with age. Vision Res 2008;38:19-29 